\title{
Granice optymalizacji podatkowej w finansach przedsiębiorstwa
}

Jolanta Iwin-Garzyńska*

\section{Wprowadzenie}

W warunkach niepewności otoczenia działalność przedsiębiorstw obarczona jest ryzykiem, które znacząco wpływa na finanse przedsiębiorstwa. Ważne jest zatem poszukiwanie rozwiązań, które będą wspomagać bieżące i strategiczne zarządzanie finansami. Do niezwykle istotnych rozwiązań dla finansów przedsiębiorstwa należą te z zakresu podatków.

Wagę podatków w polityce finansowej przedsiębiorstwa uwypuklili po raz pierwszy 45 lat temu M. Miller i F. Modigliani w teorii nieistotności struktury kapitału (Graham 2003, s. 1075-1129). Dla finansów przedsiębiorstwa miało to duże znaczenie i dało początek procesom, które dziś określa się mianem optymalizacji podatkowej.

Podatki zawsze będą powodować ryzyko i niepewność bytu przedsiębiorstwa, co wynika z dużej zmienności i niepewności prawa podatkowego. Cechą charakterystyczną polskiego systemu podatkowego jest niska jakość legislacji podatkowej. W procesie tworzenia prawa podatkowego dostrzega się istotne wady, które prowadzą do erozji prawa podatkowego, procesu niszczenia, zniekształcenia i wypaczenia systemu podatkowego, prowadzącego do ograniczenia jego przejrzystości, wzrostu stosowanych niedookreśleń i „inflacji prawa podatkowego” (Sobieska 2012, s. 52).

$\mathrm{Na}$ tym tle jawi się waga optymalizacji podatkowej, będącej świadomym i zgodnym z prawem zachowaniem, którego celem jest minimalizacja obciążeń

* Jolanta Iwin-Garzyńska, Uniwersytet Szczeciński, Wydział Nauk Ekonomicznych i Zarządzania, Katedra Finansów Przedsiębiorstwa i Podatków. 
podatkowych oraz ograniczenie ryzyka podatkowego. Celem opracowania jest przedstawienie istoty optymalizacji podatkowej z uwzględnieniem zmian w ustawie Ordynacja podatkowa dotyczących tzw. klauzuli przeciwko unikaniu opodatkowania. Proponowane zmiany stanowią swoistą granicę dla procesów optymalizacji podatkowej, a nawet mogą doprowadzić do zaniku tych procesów. Wystąpi zjawisko awersji do wszelkich działań mających na celu zarządzanie płatnościami podatkowymi, a pozostaną próby nielegalnego uchylania się od podatków.

\section{Optymalizacja podatkowa - istota}

W polskim i europejskim prawie podatkowym nie zdefiniowano pojęcia optymalizacji podatkowej. Termin ten został wypracowany przez doktrynę i praktykę stosowania przepisów prawa podatkowego. Optymalizacja podatkowa oznacza taki wybór struktury planowanej czynności (np. transakcji), który pozwala uzyskać zminimalizowanie łącznych obciążeń podatkowych (Wyciślok 2013, s. 30).

Podejmując próbę zdefiniowania optymalizacji podatkowej, należy założyć, że pojęcie to bywa używane przez praktyków w sposób intuicyjny, a więc bez rozeznania istotnych definicyjnie elementów. Warunkiem koniecznym kwalifikowania określonych działań zmierzających do minimalizacji obciążeń podatkowych jako optymalizacji podatkowej jest zgodność tych działań z prawem.

W praktyce pojęcie optymalizacji podatkowej może być kojarzone negatywnie, $\mathrm{z}$ unikaniem podatków. Jednak w optymalizacji podatkowej nie chodzi o unikanie podatków, ale o inteligentne stosowanie przepisów w celu legalnego zmniejszenia obciążeń podatkowych, czyli o „inteligencję podatkową”. Sędzia Sądu Najwyższego USA Leamed Hand stwierdził, że: „Nie ma nic niemoralnego w takim układaniu swoich spraw, które skutkuje płaceniem tak niskich podatków, jak to tylko możliwe. Każdy tak czyni, bogaty i biedny, obaj mają do tego prawo" (Wyrzykowska 2006).

Optymalizacja podatkowa to wybór wariantu realizacji wybranego rezultatu ekonomicznego, z którym wiąże się jak najmniejszy ciężar podatkowy (Ladziński 2008, s. 4). W zależności od zastosowanych rozwiązań konstrukcyjnych w danym podatku może jednak polegać nie tylko na redukcji ciężaru podatkowego, ale również na odsunięciu go w czasie, np. poprzez przesunięcie momentu powstania obowiązku podatkowego.

Optymalizacja podatkowa może być definiowana także jako konsekwencja braku regulacji podatkowo-prawnych, które wprowadzałyby nakaz ponoszenia ciężaru podatkowego w najwyższym z możliwych zakresów bądź zakaz uiszczania podatków w możliwie dopuszczalnej, najniższej wysokości. Warto wskazać, że brak takiego nakazu i zakazu skutkuje niemożliwością stosowania na gruncie podatkowym kodeksu cywilnego i konstruowania instytucji „obejścia przepisów prawa 
podatkowego". Istotą cywilnoprawnej konstrukcji obejścia prawa jest osiągnięcie skutku zakazanego przez prawo za pomocą czynności, których treść nie zawiera elementów wprost sprzecznych z ustawą. Tym samym nie jest zasadne podnoszenie wobec działań optymalizacyjnych podatników, mieszczących się w granicach dopuszczalności norm, zarzutu obejścia przepisów prawa podatkowego, skoro nie obowiązuje ani zakaz, ani nakaz w prezentowanym rozumieniu, które miałyby być przedmiotem obejścia.

W praktyce optymalizacją podatkową nazywany jest wybór przez przedsiębiorstwo takiej formy oraz struktury planowanej transakcji w ramach i granicach obowiązującego prawa podatkowego, aby w konsekwencji zmniejszyć poziom obciążeń podatkowych. Nie ma w polskim prawie podatkowym normy prawnej, która nakazywałaby firmom kształtowanie swojej sytuacji prawnej w sposób skutkujący maksymalizacją obciążenia podatkowego. Wszelkie czynności prawne, które czynią zadość prawu i służą realizacji prowadzonej działalności, a których wypadkową jest wybranie korzystniejszej formy, wysokości czy też momentu powstania obowiązku podatkowego, są zgodne z prawem. Naczelny Sąd Administracyjny w wyroku stwierdził: „Nie ma żadnej podstawy prawnej, aby przyjąć masochistyczną zasadę, że strony powinny zawsze regulować swoje stosunki cywilnoprawne w sposób najbardziej dla fiskusa korzystny" (Radwański 2000) .

W nauce prawa podatkowego w praktyce organów podatkowych i sądów administracyjnych od lat toczy się dyskusja na temat legalności planowania podatkowego prowadzącego do zmniejszenia obciążeń podatkowych. Naczelny Sąd Administracyjny w wyrokach wskazywał na konieczność racjonalnego działania przedsiębiorstwa $\mathrm{z}$ punktu widzenia finansów przedsiębiorstwa, a nie dochodów budżetu państwa. W wyroku z dnia 10.07.1996 roku stwierdził, że „żaden przepis prawa podatkowego ani orzecznictwo, ani też doktryna prawa nie zabraniają podatnikowi wyboru takiego rozwiązania, zgodnego z prawem i rzeczywistością, które byłoby dla niego, przy podejmowaniu decyzji gospodarczych, bardziej korzystne na gruncie prawa podatkowego. Wybór drogi najłagodniej opodatkowanej jest wolnym wyborem każdego podatnika i nie może podlegać kontroli organów podatkowych" (Wyrok NSA z dnia 10.07.1996). W innym wyroku Sądu orzeczono, że „istotą działalności gospodarczej jest maksymalizacja zysku, a nie zobowiązań podatkowych". Nie istnieje obowiązek działań prowadzących do zmniejszania dochodów z tego powodu, że byłoby to korzystniejsze dla budżetu państwa z punktu widzenia wpływów podatkowych (Wyrok NSA z dnia 31.01.2002). W wyroku WSA w Warszawie stwierdzono (Wyrok WSA z dnia 30.03.2004), że jeżeli obowiązujący porządek prawny stwarza podatnikowi możliwość wyboru kilku legalnych konstrukcji do osiągnięcia zamierzonego celu gospodarczego, z których każda będzie miała inny wymiar podatkowy, to wybór najkorzystniejszego rozwiązania nie może być traktowany jako obejście prawa. Z żadnej normy prawnej nie można bowiem wyprowadzić zasady nakładającej na podatnika obowiązek działania dla powstania zobowiązania podatkowego w najwyższej możliwej wysokości (Radzikowski 2010, s. 18). 
Linia orzecznictwa sądów w Polsce nie jest jednolita i także w temacie racjonalności działania miały one różne zdania. Sądy orzekały także, odwołując się do zasady konieczności płacenia podatków w tzw. należytej wysokości, rozumianej jako powinność płacenia podatków w wysokości subiektywnie odpowiadającej fiskusowi. Wyroki tego rodzaju zapadają też w ostatnim czasie (Radzikowski 2010, s. 18).

Niepewność orzecznictwa sądów w temacie optymalizacji podatkowej wynika także $\mathrm{z}$ tego, jak trudno uchwytne są granice legalności ${ }^{1}$ i granice optymalizacji podatkowej. Najtrudniejsza do uchwycenia jest granica między unikaniem opodatkowania a oszustwem podatkowym.

\section{Cel optymalizacji podatkowej w przedsiębiorstwie}

Z definicji optymalizacji podatkowej wynika, że jest ona wyborem takiego wariantu realizacji założonego rezultatu finansowego, z którym wiązać się będą jak najmniejsze obciążenie podatkowe, a tym samym przepływy podatkowe. Stąd zasadniczym celem optymalizacji podatkowej będzie minimalizacja obciążeń podatkowych zarówno w okresie bieżącym, jak i w czasie przyszłym (długoterminowe planowanie podatkowe). Pochodną tego celu będzie zwiększenie przepływów finansowych przedsiębiorstwa, które pozostaną do dyspozycji przedsiębiorstwa w wyniku oszczędności na płatnościach podatkowych. Zatem celem optymalizacji podatkowej jest zwiększenie wyniku finansowego netto, strumienia środków pieniężnych, których skutkiem będzie wzrost wartości aktywów przedsiębiorstwa.

W finansach przedsiębiorstwa minimalizacja obciążeń podatkowych nie może być celem samym w sobie. Przedsiębiorstwo, podejmując decyzję w przedmiocie wyboru wariantu korzystniejszego z punktu widzenia wysokości obciążeń podatkowych, musi brać pod uwagę bardzo wiele innych czynników, takich jak na przykład ogólne bezpieczeństwo prawne transakcji oraz wszelkie dodatkowe koszty wiążące się z realizacją danego wariantu. Bardzo często istotnym elementem, który należy uwzględnić, jest gotowość drugiej strony transakcji do zaakceptowania korzystniejszego podatkowo wariantu jej realizacji. Przyjmując, że celem optymalizacji podatkowej jest zwiększenie wyniku finansowego netto poprzez minimalizację obciążeń podatkowych, należy stwierdzić, że efektem tych działań musi być wzrost wartości przedsiębiorstwa. Jest to wniosek wynikający z teorii M. Millera i F. Modiglianiego, klasyki teorii finansów przedsiębiorstwa (por. Modigliani, Miller 1958; Modigliani, Miller 1963; Miller 1988).

1 O trudności uchwycenia tych granic dowodzą także zmiany w Ordynacji podatkowej. 


\section{Optymalizacja podatkowa a klauzula przeciwko unikaniu opodatkowania}

Bezpieczna optymalizacja podatkowa związana jest $\mathrm{z}$ obowiązującymi normami prawa, w których określono zakres uprawnień organów podatkowych w przedmiocie oceny skutków podatkowych dokonywanych przez przedsiębiorstwo działań. Na podstawie zapisów ustawy ordynacja podatkowa (Ustawa z dnia 29.08.1997) można dokonać ustalenia granic, w jakich przedsiębiorstwa mogą się poruszać, poszukując optymalnych, z ich punktu widzenia, rozwiązań, które mogą zapewnić niższe opodatkowanie osiąganych rezultatów aktywności gospodarczej. W działaniach przedsiębiorstwa najtrudniejsza do uchwycenia jest granica między unikaniem opodatkowania a oszustwem podatkowym.

Uchylanie się od opodatkowania (tax evasion) jest sprzeczne z powszechnie obowiązującymi normami prawa podatkowego, co w konsekwencji prowadzi do traktowania tego zjawiska jako przestępstwa, defraudacji podatkowej, za które przewidziana jest odpowiedzialność karna (np. niewykazywanie przedmiotu opodatkowania, chociażby poprzez nieewidencjonowanie obrotu przez zobowiązanych do tego podatników za pomocą kasy fiskalnej).

Natomiast unikanie opodatkowania (tax avoidance), w granicach którego mieści się optymalizacja podatkowa, jest działaniem w ramach prawa, które skutkuje redukcją zobowiązań podatkowych (np. zwiększenie podstawy amortyzacji).

Oceny działań podejmowanych przez przedsiębiorstwo dokonuje organ podatkowy, a często w efekcie sąd. Do lipca 2016 roku brak było w polskim prawie podatkowym przepisu zawierającego klauzulę obejścia prawa podatkowego ${ }^{2}$, a tym samym brak norm zakazujących optymalizacji podatkowej - korzystania z przewidzianych przez prawo możliwości zmniejszenia swoich zobowiązań podatkowych przy zastosowaniu legalnych środków działania. Trybunał Konstytucyjny w wyroku z dnia 11 maja 2004 roku orzekł: „Jeśli więc adresat dokonuje czynności prawnych zgodnych z prawem, zaś ich cel nie jest przez prawo zakazany, to tym samym trudno uznać za prawidłowe i właściwe takie ich kwalifikowanie, które osiągnięty cel (także podatkowy) traktuje na równi z celami zakazanymi” (Wyrok Trybunału Konstytucyjnego z dnia 11.05.2004).

W obowiązujących zapisach ustawy ordynacja podatkowa (Wyrok Trybunału Konstytucyjnego z dnia 11.05.2004) wskazano, że organy podatkowe, dokonując ustalenia treści czynności prawnej, mają obowiązek uwzględnić zgodny zamiar stron oraz cel czynności, a nie tylko dosłowne brzmienie oświadczeń woli złożonych przez strony czynności. Wynika stąd, że interpretacja postanowienia umowy, znaczeniowo niejasnego, nie może być oparta tylko na analizie językowej, lecz konieczne jest zbadanie zamiaru i celu stron, a także kontekstu faktycznego, w jakim umowę uzgadniano i zawierano (Wyrok Sądu Najwyższego z dnia 3.09.1998).

2 Wcześniej, art. 24b Ordynacji podatkowej. 
Wcześniejszy stan prawny w zakresie normatywnych granic ingerencji organów podatkowych $\mathrm{w}$ sferę stosunków cywilnoprawnych podatników został ukształtowany w wyniku wyroku Trybunału Konstytucyjnego z dnia 11 maja 2004 roku, w którym Trybunał orzekł niezgodność z konstytucją zapisów ordynacji podatkowej ${ }^{3}$, zgodnie z którymi: „organy podatkowe i organy kontroli skarbowej, rozstrzygając sprawy podatkowe, pominą skutki podatkowe czynności prawnych, jeżeli udowodnią, że z dokonania tych czynności nie można było oczekiwać innych istotnych korzyści niż wynikające z obniżenia wysokości zobowiązania podatkowego, zwiększenia straty, podwyższenia nadpłaty lub zwrotu podatku”. Wyrok spowodował przełom w podejściu do problematyki „obejścia prawa podatkowego”.

Fundamentem stanowiska Trybunału Konstytucyjnego było stwierdzenie, że dokonanie czynności prawnej zgodnej z prawem, a więc również takiej, której cel przez prawo nie jest zakazany, nie może być na gruncie przepisów prawa podatkowego kwalifikowane w taki sposób, aby osiągnięty przez dokonanie takiej czynności cel podatkowy był traktowany jako cel zakazany. Trybunał podkreślił, iż w systemie prawa podatkowego brak jest normy, która zakazywałaby niższego opodatkowania, o ile podatnik realizuje ten cel przy zastosowaniu legalnych środków działania. W dalszej części uzasadnienia wyroku Trybunał Konstytucyjny stwierdził: „Brak bowiem de lege lata normy prawnej, która za niedozwolone uznawałaby zachowania podatnika zmierzające do obniżenia (uniknięcia) opodatkowania. Podejmowane przez podatnika czynności pozostają zatem ważne nie tylko z punktu widzenia prawa cywilnego, bo w szerszym wymiarze stwierdzić można ich legalność o charakterze systemowym, wobec braku normy prawnej zakazującej ich dokonywania”.

Podsumowując przedstawione rozważania, należy wskazać na fakt, że obowiązujące zapisy ordynacji podatkowej zawiera klauzulę, a organ podatkowy jest uprawniony do tego, by pominąć skutki podatkowe czynności prawnej, jeśli udowodni, że czynność prawna dokonana została jedynie w celu osiągnięcia korzyści podatkowej. Nowe przepisy zostały zawarte w dodanym do ustawy Ordynacja podatkowa ${ }^{4}$ dziale IIIa „Przeciwdziałanie unikaniu opodatkowania” i obowiązują od 15 lipca 2016 roku.

Jeszcze w wyroku z dnia 15 stycznia 2016 roku. Naczelny Sąd Administracyjny (Wyrok NSA z dnia 15.01.2016) wskazał, że przeciwko działaniom podatników, mającym znamiona obejścia prawa podatkowego lub nadużycia prawa podatkowego, organy podatkowe mogą przeciwdziałać, ale dysponują w zasadzie tylko jedną

3 Ustawa ordynacja podatkowa, brzmienie art. 24b.

$\S 1$. Organy podatkowe i organy kontroli skarbowej, rozstrzygając sprawy podatkowe, pominą skutki podatkowe czynności prawnych, jeżeli udowodnią, że z dokonania tych czynności nie można było oczekiwać innych istotnych korzyści niż wynikające z obniżenia wysokości zobowiązania podatkowego, zwiększenia straty, podwyższenia nadpłaty lub zwrotu podatku.

$\S 2$. Jeżeli strony, dokonując czynności prawnej, o której mowa w $\S 1$, osiągnęły zamierzony rezultat gospodarczy, dla którego odpowiednia jest inna czynność prawna lub czynności prawne, skutki podatkowe wywodzi się z tej innej czynności prawnej lub czynności prawnych Wyrokiem Trybunału Konstytucyjnego z dnia 11 maja 2004 r., art. 24 b § 1 Ordynacji podatkowej został uznany za niezgodny $z$ art. 2 w związku z art. 217 Konstytucji. 
możliwością, tj. instrumentami zawartymi w art. 199a $\$ 1$ i 2 ordynacji podatkowej (Winiarski 2015, s. 106). Zdaniem Sądu art. 199a $\$ 2$ Ordynacji podatkowej mógł mieć zastosowanie jedynie w przypadku stwierdzenia w obrocie pozornej czynności prawnej, a nie czynności dokonanej w celu uzyskania zamierzonego efektu podatkowego - optymalizacji podatkowej, która jednak nie nosi cech pozorności.

\section{Wprowadzenie klauzuli przeciwko unikaniu opodatkowania}

Przy analizie optymalizacji podatkowej szczególnego znaczenia nabiera wprowadzenie tzw. klauzuli przeciwko unikaniu opodatkowania do zapisów ustawy ordynacja podatkowa w roku 2016.

Historia ponownego wprowadzenia klauzuli do polskiego prawa podatkowego sięga roku 2013. W dniu 30 kwietnia 2013 roku Ministerstwo Finansów opublikowało dokument „Założenia projektu ustawy o zmianie ustawy - Ordynacja podatkowa oraz niektórych innych ustaw”. Prace legislacyjne były wówczas na etapie założeń - nie było konkretnych propozycji przepisów, ale już same założenia budziły obawy wśród przedsiębiorstw, gdyż celem ministra finansów była, i jest nadal, chęć ograniczenia wykorzystywania optymalizacji podatkowej.

Klauzula przeciwko unikaniu opodatkowania to zapis prawny (ustawowy), który uprawnia organy administracji podatkowej do kwestionowania prawa podatników do zawierania transakcji, które pozostają zgodne z dosłownym brzmieniem przepisów, lecz są sformułowane w taki sposób, by osiągnąć efekt inny od zamierzonego przez ustawodawcę. W projektowanych przepisach znalazła się definicja legalna unikania opodatkowania, zgodnie $\mathrm{z}$ art. 25a, „unikaniem opodatkowania będzie zastosowanie w sposób zamierzony sztucznej konstrukcji prawnej, której głównym celem było uzyskanie nieprzewidzianej w przepisach prawa podatkowego oraz sprzecznej z celem i istotą tych przepisów znacznej korzyści podatkowej przez podmiot tworzący lub współtworzący sztuczną konstrukcję prawną”. W praktyce proponowany zapis będzie narzędziem organów podatkowych do walki z agresywnym planowaniem podatkowym (agresywną optymalizacją podatkową), czyli sposobem zawierania transakcji, w których przedsiębiorstwo dąży do obniżenia wysokości zobowiązania podatkowego.

Klauzula ma uniemożliwiać dokonywanie sztucznych i niemających uzasadnienia gospodarczego czynności, które mogą posłużyć do ominięcia przepisów i osiągnięcia korzyści podatkowych. Jeżeli urzędnicy zauważą, że dana czynność podatnika została podjęta przede wszystkim lub wyłącznie w celu obniżenia podatku, będą mogli taki podatek określić we właściwej wysokości. Klauzulę będzie można zastosować tylko wtedy, gdy korzyść podatkowa w jednym roku podatkowym przekroczy 100 tys. zł. 
Z punktu widzenia istoty finansów przedsiębiorstwa wątpliwości budzi założenie, że klauzula przeciwko unikaniu opodatkowania ma być stosowna w sytuacji, gdy przeprowadzane przez przedsiębiorstwo transakcje nie miałyby uzasadnienia ekonomicznego, a ich głównym celem byłoby uzyskanie korzyści podatkowej (np. przez obniżenie wysokości podatku). W świetle idei optymalizacji podatkowej można zadać pytanie: czy legalne obniżenie płaconych podatków nie ma uzasadnienia finansowego? Z punktu widzenia finansów przedsiębiorstwa oczywiście tak, gdyż każde zmniejszenie obciążeń podatkowych to działalnie tarczy podatkowej i zmniejszenie wypływów pieniężnych z przedsiębiorstwa.

Z praktycznego punktu widzenia wprowadzenie zmian w ordynacji podatkowej ma ogromne znaczenie, gdyż niemal każde działanie przedsiębiorcy, które doprowadzi do zmniejszenia jego obciążeń podatkowych, a którego wartość przekroczy 100 tys. zł., może zostać uznane za obejście przepisów prawa podatkowego.

Przedsiębiorstwo, które będzie chciało przeprowadzić optymalizację podatkową, może wystąpić o tzw. opinię zabezpieczającą. W opinii podatnik uzyska wyjaśnienie, jakie jego działanie będzie uznane za dopuszczalną optymalizację podatkową, a jakie - za unikanie opodatkowania. Innymi słowy w opinii określone zostanie, czy planowane przez przedsiębiorstwo działanie stanowi dopuszczalną optymalizację podatkową, czy też jest niedozwolonym unikaniem opodatkowania. Trudności z wprowadzeniem do praktyki tego rozwiązania mogą wynikać z faktu, że opłata za wydanie opinii zabezpieczającej ma wynosić 20000 zł, a okres oczekiwania na opinię wynosiłby nawet 6 miesięcy.

Powołana została także niezależna od administracji skarbowej Rada do Spraw Przeciwdziałania Unikaniu Opodatkowania, której zadaniem jest opiniowanie zasadności stosowania klauzuli w indywidualnych sprawach. W uzasadnieniu wzbogacenia administracji skarbowej o nowy podmiot zapisano „Tym samym polski system zwalczania unikania opodatkowania będzie w dużym stopniu korzystał ze standardów bezpieczeństwa wypracowanych przez inne kraje”.

Według resortu finansów unikanie opodatkowania to tworzenie sztucznych, oderwanych od realiów gospodarczych konstrukcji prawnych dla uzyskania korzyści podatkowych, najczęściej polegających na uniknięciu lub obniżeniu kwoty podatku. W wyjaśnieniach ministerstwa finansów zapisano „Standardem w innych rozwiniętych gospodarczo krajach jest klauzula generalna przeciwko unikaniu opodatkowania albo rozwinięta linia orzecznictwa sądowego, zwalczająca nadużycia podatkowe. Polska należy obecnie do nielicznych krajów, gdzie nie ma takich instrumentów, a wprowadzenie klauzuli zaleca Komisja Europejska”.

Zalecenia Komisji Europejskiej zawarto w dokumencie z dnia 6 grudnia 2012 roku w sprawie agresywnego planowania podatkowego (Zalecenia Komisji Europejskiej z dnia 6.12.2012), w którym zapisano „Nie uwzględnia się sztucznego uzgodnienia lub szeregu sztucznych uzgodnień, które przyjęto w zasadniczym celu uniknięcia opodatkowania i które prowadzą do osiągnięcia korzyści podatkowej. Krajowe organy rozpatrują te ustalenia do celów podatkowych poprzez odniesie- 
nie się do ich istoty ekonomicznej”. TSUE zalicza zasadę zakazu nadużycia prawa wspólnotowego do ogólnych zasad opodatkowania podatkiem VAT. W swej opinii Rzecznik TSUE wskazał, że „każdy porządek prawny, który dąży do osiągnięcia minimalnego stopnia realizacji, musi zawierać środki ochrony własnej, aby zapewnić, że wykonywanie przyznawanych przezeń praw nie stanowi nadużycia ani nie następuje w sposób nadmierny lub wypaczony. Ten wymóg wcale nie jest obcy prawu wspólnotowemu" (Nykiel, Zalasiński 2014, 1252).

Wprowadzenie klauzuli niewątpliwie wyznaczyło granice dopuszczalnej optymalizacji podatkowej, ale czy zmiana będzie pozytywnie oddziaływać na konkurencyjność na rynku i zapewni równe traktowanie przedsiębiorców? Trudno dziś o odpowiedź na to pytanie.

\section{Podsumowanie}

Istota optymalizacji podatkowej jest szczególnie ważna właśnie w dobie spowolnienia gospodarczego oraz w obliczu zapowiadanych przez ministerstwo finansów zmian w prawie podatkowym.

Do czasu pojawienia się na świecie kryzysu finansowego niewielu polskich przedsiębiorców wiedziało, czym jest optymalizacja podatkowa. Większość z nich prowadziła politykę podatkową dostosowaną do strategii ekspansji i prosperity, nie zważając na potrzeby ciągłego optymalizowania swoich wydatków. W sytuacji wystąpienia ryzyka pojawienia się strat na działalności oraz konieczności zwolnień pracowników, a w dalszej kolejności bankructwa, przedsiębiorcy zostali zmuszeni do korekty prowadzonej przez siebie polityki. Jednym z obszarów potencjalnych oszczędności w przedsiębiorstwie są z pewnością obciążenia podatkowe, których racjonalizacja może przyczynić się do zwiększenia konkurencyjności w okresie obniżonej koniunktury. Punktem wyjścia do podjęcia działań optymalizacyjnych jest zrozumienie zagadnień związanych z tym pojęciem, uświadomienie ryzyka oraz pogłębiona analiza prowadzonych przez firmę działań dnia codziennego. Optymalizacja podatkowa powinna być jednym z elementów strategii funkcjonowania każdej firmy, a płatnościami podatkowymi należy mądrze zarządzać. Wprowadzenie klauzuli przeciwko unikaniu opodatkowania w proponowanym brzmieniu to zwiększenie ryzyka podatkowego w finansach przedsiębiorstwa oraz wyznaczenie granic optymalizacji podatkowej.

5 Opinia rzecznika generalnego Tesauro z dnia 4 lutego 1998 r. w sprawie C-367/96 Kefalas, pkt 24. 


\section{Bibliografia}

Graham J.R. (2003), Taxes and Corporate finance: A Review, Duke University, The Review of Financial Studies, Winter, Vol. 16, No. 4. p. 1075-1129.

Miller M.H. (1977), Debt and Taxes, Journal of Finance, Nr 32.

Miller M.H. (1988), The Modigliani-Miller Propositions After Thirty Years, Journal of Economic Perspectives, $\mathrm{Nr} 4$.

Modigliani F., Miller M.H. (1958), The Cost of Capital, Corporation Finance and the Theory of Investment, American Economic Review, Nr 48.

Modigliani F., Miller M.H. (1963), Corporate Income, Taxes and the Cost of Capital. A Correction, American Economic Review, Nr 53.

Ladziński A. (2008), Prawne granice optymalizacji podatkowej, Przegląd Podatkowy, Nr 6.

Nykiel W., Zalasiński A. (2014), Orzecznictwo Trybunału Sprawiedliwości Unii Europejskiej w sprawach podatkowych, Komentarz, Wolters Kluwer, Warszawa.

Radwański Z. (2000), Glosa do wyroku NSA z 11.11.1999 r., OZ Białystok SA/Bk 289/99, OSP, nr 9, poz. 135a.

Radzikowski K. (2010), Obejście prawa podatkowego w najnowszym orzecznictwie sądów administracyjnych, Przegląd Podatkowy, Nr 6.

Sierpińska M., Niedbała B. (2003), Controlling operacyjny w przedsiębiorstwie, Wydawnictwo Naukowe PWN, Warszawa.

Sobieska I. (2012), Doradztwo podatkowe. Funkcjonowanie i kierunki rozwoju, Lex, Wolters Kluwer Polska, Warszawa.

Winiarski K. (2015), Klauzula przeciwko unikaniu opodatkowania a obejście i nadużycie praw podatkowego, Przegląd Prawa Publicznego, Nr 12.

Wyciślok J. (2013), Optymalizacja podatkowa. Legalne zmniejszanie obciążén podatkowych, C.H. Beck, Warszawa.

Wyrzykowska A. (2006), Optymalizacja - legalnym wyborem podatnika?, Fiskus, Nr 8.

\section{Wyroki sądowe i akty prawne}

Zalecenia Komisji Europejskiej z dnia 6.12.2012 r. w sprawie agresywnego planowania podatkowego, Dz.Urz. UE L338 z 12.12.2012.

Ustawa z dnia 29.08.1997 r. ordynacja podatkowa, Dz.U. z 2005 r. nr 8, poz. 60 z późn.zm.

Wyrok Trybunału Konstytucyjnego z dnia 11.05.2004 r., sygn. K 4/03, Dz.U. Nr 122, poz. 1288.

Wyrok Sądu Najwyższego z dnia 3.09.1998 r. I CKN 815/97, OSNC 1999, nr 5, poz. 38.

Wyrok NSA z 15.01.2016 r., sygn. akt II FSK 3162/13.

Wyrok NSA z dnia 10.07.1996 r. (SA/Ka 1244/95, „Monitor Podatkowy” 1997/8, s. 239-243).

Wyrok NSA z dnia 31.01.2002 r. (I S.A./Gd771/01 „Doradztwo Podatkowe” 2003/2, s. 64-67).

Wyrok WSA w Warszawie z dnia 30.03.2004 r. (III SA/Wa 1195/05, LEX nr 181010). 


\section{GRANICE OPTYMALIZACJI PODATKOWEJ W FINANSACH PRZEDSIĘBIORSTWA}

\section{Streszczenie}

Celem opracowania jest przedstawienie istoty optymalizacji podatkowej z uwzględnieniem propozycji zmian w Ordynacji podatkowej dotyczącej klauzuli przeciwko unikaniu opodatkowania. Proponowane zmiany stanowią swoistą granicę dla procesów optymalizacji podatkowej, a nawet mogą doprowadzić do zaniku tych procesów. Wystąpi zjawisko awersji do wszelkich działań mających na celu zarządzanie płatnościami podatkowymi, a pozostaną próby nielegalnego uchylania się od podatków.

Słowa kluczowe: podatek dochodowy, optymalizacja podatkowa, klauzula przeciwko unikaniu opodatkowania

\section{THE LIMITS OF TAX OPTIMIZATION IN THE CORPORATE FINANCE}

\section{Summary}

The aim of the study is to present the essence of tax optimization with regard to proposals for changes in the Tax Code relating to the clause against tax evasion. The proposed changes constitute a specific limit for tax optimization processes, and may even lead to the disappearance of these processes. There is effect aversion to any action aimed at managing tax payments, and will remain illegal attempts to tax evasion.

Keywords: income tax, tax optimization, clause against tax evasion 